\title{
KONSTRUKSI SOSIAL REMAJA OSING TERHADAP RITUS BUYUT CILI SEBAGAI CIVIC CULTURE UNTUK PEMBENTUKAN JATIDIRI
}

\author{
Agus Suprijono, Gurniwan Kamil Pasya \\ Dosen Fakultas Ilmu Sosial UNESA \\ email: agussuprijono@yahoo.com
}

\begin{abstract}
ABSTRAK
Fokus penelitian adalah eksternalisasi, objektivasi, dan internalisasi remaja Osing terhadap Buyut Cili serta kesadaran diri atau konstruksi diri. Tujuan penelitian mendeskripsikan pembentukan pengetahuan, internalisasi nilai, dan motif tindakan serta identifikasi kesadaran diri. Metode penelitian fenomenologi, teknik pengumpulan data observasi, wawancara, dan dokumentasi. Hasil penelitian adalah remaja Osing dalam konstruksi sosial terhadap realitas sosial dan budaya masyarakatnya mampu mengembangkan domain psiko-sosial yakni kebiasaan berpikir dan bersikap yang menopang berkembangnya harmonisasi kehidupan sosial dan komitmen sebagai anggota masyarakat yang bernalar dan diterima dengan sadar terhadap nilai dan prinsip hidup berdemokrasi.
\end{abstract}

Kata kunci: konstruksi sosial, ritus buyut cili, civic culture, jatidiri

\section{ABSTRACT}

This research focuses on Osing teenagers' externalizing, objectivization, internalization toward Buyut Cili rites and self construction. Research purpose is to describe the externalization and objectivization that is displayed by Osing teenagers toward Buyut Cili rites, to find out knowledge, value, reasons to perform and the self-construction. This is a qualitative research. Data is collected through observation, interview and documentation. The results are Osing teenagers develop psycho-social domains that habit of thinking and behaving that support the development of social harmony and commitment as members of the public who received conscious reasoning and the values and principles of democracy alive.

Keyword: social construction, buyut cili rites, civic culture, identity

\section{PENDAHULUAN}

Ritus Buyut Cili merupakan fenomena esoterisme agama budaya Osing di Banyuwangi. Esoterisme ini bersumber dari mitos Buyut Cili sebagai warisan sosial. Ritus Buyut Cili tidak hanya menjadi pengetahuan bagi masyarakat Osing, tetapi fenomena tersebut juga menjadi pengalaman hidup dan bagian dari sistem kepercayaan atau religi. Ritus Buyut Cili menjadi nilai sentral yaitu sumber utama orientasi, sikap, dan tindakan sosial Osing. Ritus Buyut Cili adalah pranata bagi masyarakat Osing.

Ritus Buyut Cili sebagai mitos merupakan hal penting dalam religi Osing. Dhavamony (1995 : 147) mengemukakan "mitos berasal dari bahasa Yunani muthos secara harfiah diartikan sebagai cerita atau sesuatu yang dikatakan seseorang". Menurut Thompson (1990 : 26) setiap mitos “... is a partial representation of reality". Mitos merupakan representasi dari realitas. Eliade (2002 : 95) mengemukakan bahwa "realitas mitos adalah kenyataan yang suci; kesucian sebagai satusatunya kenyataan tertinggi ; kesucian menghadirkan dirinya sebagai sesuatu yang sama sekali berbeda dari kenyataan biasa, kenyataan yang sesungguhnya dipenuhi dengan kekuatan". Mitos merupakan realitas yang suci, menceritakan mitos berarti menyingkapkan sebuah misteri. Endraswara (2003 : 193) mengemukakan mitos adalah:

Cerita suci berbentuk simbolik yang mengisahkan serangkaian nyata dan imajiner menyangkut asal-usul dan perubahan-perubahan alam raya dan dunia, dewa-dewi, kekuatan-kekuatan atas kodrati, manusia, pahlawan, dan masyarakat. Ciri mitos adalah memiliki sifat suci atau sakral, karena terkait dengan tokoh yang sering dipuja. Mitos 
seringkali sulit dipahami kebenarannya, dan sering bersumber dari tempat-tempat sakral.

Mitos memberi makna religius. Danandjaja (1994 : 50) berpendapat mitos sebagai cerita prosa rakyat memiliki karakteristik sebagai berikut:

Mitos dianggap benar-benar terjadi serta dianggap suci oleh yang empunya cerita. Mitos ditokohkan oleh para dewa atau makhluk setengah dewa. Peristiwa terjadi di dunia lain atau di dunia yang bukan seperti kita kenal sekarang dan terjadi pada masa lampau.

O’dea (1996 : 79) mengemukakan bahwa "mitos merupakan aspek institusionalisasi religi dan mitos adalah bentuk pengungkapan intelektual yang primordial dari berbagai sikap dan kepercayaan keagamaan".

Masyarakat Osing selain dikenal sebagai masyarakat yang terbuka menerima masuknya unsur-unsur kebudayaan modernitas, masyarakat Osing juga masih sangat kuat berpegang teguh pada tradisi religio-magis warisan leluhurnya. Peristiwa menghebohkan pembantaian dukun santet yang terjadi pada tahun 1998 di Banyuwangi setidaknya keberadaaan dukun dalam peristiwa itu mencitrakan suatu fenomena budaya bahwa masyarakat Osing masih akomodatif dengan dunia klenik, magis, mistis, dan sejenisnya. Saputra (2008 : 59) mengemukakan.

\section{Kehidupan keagamaan Osing didominasi oleh Islam yang mencapai 95\% lebih, Kristen dan Katolik 2,68\%, serta Hindu 1,49\%. Osing dicitrakan sebagai masyarakat yang sangat kuat dengan dunia magis hal ini tidak dapat dilepaskan dari fungsi mekanisme mistis bagi terciptanya tertib sosial.}

$\begin{array}{llr}\text { Sunarlan } & (2008: 132) & \text { menyatakan } \\ \text { "masyarakat } & \text { Osing masih berpegang } \\ \text { teguh pada } & \text { kekuatan-kekuatan magis". } \\ \text { Subaharianto } & (1996: 3) \text { juga berpendapat }\end{array}$

bahwa "orang Osing yang diprasangkai sebagai sosok yang kasar (tidak punya tata krama) memiliki ilmu gaib destruktif yang disebut santet, pelet, sihir, dan sebangsanya". Di sinilah keunikan masyarakat Osing selain sebagai pemeluk agama besar masyarakat Osing masih melestarikan kebudayaan nenek moyang hingga sekarang.

Remaja Osing tumbuh dan berkembang dalam masyarakat Osing yang terbuka terhadap modernitas di satu sisi, namun di sisi lain remaja Osing juga tumbuh dan berkembang dalam kebudayaan rohani bersifat religio-magi yang masih dipegang teguh masyarakatnya. Remaja Osing hidup dalam dialektika modernitas dan tradisional. Remaja Osing hidup di masyarakat yang masih sangat kuat berpegang teguh pada tradisi nenek moyang. Masyarakat Osing sangat percaya kepada dunia supranatural yang dilingkupi oleh unsur kekuatan gaib dan magis. Remaja Osing hidup di tengah masyarakat yang masih kuat menjaga kesinambungan kebudayaan leluhur di masa lampau. Remaja Osing menghadapi ritus Buyut Cili sebagai kenyataan sosial. Berdasarkan perspektif agama besar khususnya Islam, sistem kepercayaan masyarakat Osing ini dianggap berseberangan dengan ketauhidan.

Kebudayaan memberi rangsangan terhadap perkembangan kepribadian individu-individu sebagai anggota masyarakat. O'dea (1996:6) menyatakan "kebudayaan, sistem sosial, dan kepribadian merupakan tiga aspek dari suatu kompleksitas fenomena sosial terpadu yang pengaruhnya dapat diamati dalam perilaku manusia". Kebudayaan esoterisme agama budaya Osing sebagai sistem makna-makna simbolis sebagian di antaranya menentukan realitas sebagaimana dipahami dan sebagian lainnya menentukan harapan-harapan normatif yang dibebankan kepada individuindividu remaja Osing sebagai anggota masyarakat. Kebudayaan esoterisme agama budaya Osing mempengaruhi kelakuan remaja Osing. Kebudayaan esoterisme 
agama budaya Osing berpengaruh terhadap pembentukan jatidiri remaja Osing melalui konstruksi sosial.

Peter L. Berger dan Thomas Luckmann adalah penggagas konsep konstruksi sosial. Pemikirannya dipaparkan di dalam karya berjudul The Social Construction of Reality yang dipublikasikan pada tahun 1966. Sosialisasi merupakan elemen penting yang secara simultan berdialektika dengan eksternalisasi dan objektivasi dalam proses konstruksi sosial, yaitu terkonstruksinya realitas pada diri individu secara subjektif dan terbentuknya realitas di tengah-tengah masyarakat.

Konsep konstruksi sosial Berger dan Luckmann dikatakan oleh Riyanto (2009: 72) sebagai berikut:

Pemikiran Berger tentang konstruksi sosial merupakan pemikiran eklektis yang mensintesakan dua asumsi tentang realitas sosial yaitu pertama asumsi Weber bahwa realitas sosial merupakan hasil pemaknaan subjektif dan kedua asumsi Durkheim bahwa realitas sosial merupakan realitas sosial objektif.

Konstruksi sosial merupakan proses bagaimana kenyataan sosial terkonstruksi menjadi pengetahuan yang memiliki maknamakna subjektif bagi individu-individu sebagai anggota masyarakat. Dalam konstruksi sosial manusia dipandang sebagai insan kreatif yang memiliki kemampuan mengartikulasikan makna secara individual dan sosial, memiliki kebebasan memilih, dan menentukan cara maupun tujuan bertindak. Manusia mempunyai kemampuan voluntaristik dalam kebudayaan masyarakatnya. Dalam perspektif konstruksi sosial manusia dianggap selalu bertindak sebagai agen dengan mengkonstruksi realitas kehidupan sosial. Menurut Suparno (1997 : 21) "pengetahuan bukanlah sebagai gambaran dunia kenyataan belaka, tetapi selalu merupakan konstruksi kenyataan melalui kegiatan subjek".

Berdasarkan pemikiran Piaget, remaja memasuki perkembangan kognitif ke tahap operasi formal dengan ciri pokok berpikir hipotesis, logis, dan abstrak. Remaja Osing dalam menghadapi esoterisme agama budaya Osing yang bertentangan dengan ketauhidan dapat melakukan refleksi terhadap situasi dan kondisi masyarakat dan dirinya, mencari pemecahan atas persoalan-persoalan yang dialaminya, serta mempertimbangkan dan memperhitungkan berdasarkan kerangka berpikirnya. Remaja Osing tidak hanya mampu memadukan gambaran realitas masyarakat Osing dan kebudayaannya dalam skemata yang sudah dimilikinya untuk dicocokkan dengan lingkungan, tetapi remaja Osing juga mempunyai kemampuan mengubah skemata berhubungan dengan lingkungannya. Remaja Osing memiliki kemampuan beradaptasi dengan lingkungan sesuai perkembangan kognitifnya.

Konstruksi sosial remaja Osing terhadap esoterisme agama budaya Osing merupakan proses yang menggambarkan bagaimana pengetahuan umum atau kenyataan sosial kehidupan sehari-hari masyarakat dan kebudayaannya terkonstruksimenjadimaknamakna subjektif dalam dirinya ; bagaimana remaja Osing bertindak atas maknamakna tersebut; bagaimana remaja Osing mengorganisir pengalaman tentang dunia sosialnya yang bermakna secara subjektif bagi dirinya. Berdasarkan makna dan cara bertindak, konstruksi sosial memberikan deskripsi mengenai kemampuan remaja Osing mengambil keputusan. Kemampuan ini merepresentasikan wujud kesadaran atau jatidiri.

Konstruksi sosial menjelaskan bagaimana realitas sosial objektif terkonstruksi dalam kesadaran subjektif individu. Waters (1994: 35) menyatakan bahwa konstruksi sosial yang dikembangkan Berger bertolok pada premis “...Human beings construct social reality in which subjective processes can 
become objectified". Masyarakat sebagai realitas objektif dalam perspektif pemikiran Berger tidak harus positivistik. Objektif adalah orientasi nilai terkait dengan budaya. Menurut Berger (1994 : 8) "kebudayaan terdiri atas totalitas produk-produk manusia, baik yang berupa material dan nonmaterial". Pendefinisian seperti ini tidak hanya memandang kebudayaan sebagai artifak materi dan non-materi yang membimbing tingkah laku manusia, tetapi kebudayaan juga merupakan refleksi atas dunianya dengan kesadaran manusia. Produk manusia berupa makna subjektif dan intensionalitas turut memproduksi kebudayaan. Kebudayaan akan eksis apabila masyarakat memiliki kesadaran terhadapnya.

Ritus Buyut Cili merupakan realitas objektif. Remaja Osing sejak dilahirkan mengalami reifikasi terhadap realitas itu. Remaja Osing menghadapi realitas sosial ritus Buyut Cili sebagai kenyataan bernilai eksterioriti. Remaja Osing mengalami eksternalisasi dan objektivasi ritus Buyut Cili sebagai fakta sosial.

Lukes (1972 : 9-10) menganalisis elemen fakta sosial sebagai realitas sosial objektif baik material maupun nonmaterial sebagai berikut:

\section{The major levels of social reality in Durkheim's} work can be depicted as follows (1) Material social facts ...society, structural components of society, morphological component of society ; (2) Nonmaterial social facts ... morality, collective conscience, collective representations, social currents.

Mauss dan Fauconnet tidak menggunakan istilah fakta sosial menyebut realitas sosial yang eksternal dan objektif itu. Istilah yang digunakan adalah social institution atau pranata sosial. Vera Godoy (1971 : 52) mengemukakan institusi sosial adalah '...institution to include ways of acting and thinking that the individual finds preestablished,... already made, ...imposed more or less on him... and that will survive him'.
Pranata sosial mencakup cara-cara bertingkah laku dan bersikap yang tidak terbentuk dan telah diketemukan oleh individu di dalam pergaulan hidup di mana individu kemudian menjadi bagian dari padanya, sehingga cara-cara bertingkah laku dan bersikap diketemukannya itu memaksanya untuk menurutinya dan mempertahankannya. Dalam sosiologi modern pranata sosial cenderung dipandang sebagai hubungan antar norma-norma dan nilai-nilai yang mengitari aktivitas manusia. Sebagaimana dikatakan Ritzer (1980 : 47) "In modern sociology, institutions tend to be viewed as interrelated sets of norms and values that surround a particular human activity.

Dalam pemikiran Berger selain masyarakat dipahami sebagai realitas objektif, masyarakat juga dipahami sebagai kenyataan subjektif yang dilakukan melalui internalisasi. Internalisasi adalah pemahaman atau penafsiran individu secara langsung atas peristiwa objektif sebagai pengungkapan makna. Berger dan Luckmann (1990:87) menyatakan, "dalam internalisasi, individu mengidentifikasikan diri dengan berbagai lembaga sosial atau organisasi sosial di mana individu menjadi anggotanya". Internalisasi merupakan peresapan kembali realitas oleh manusia dan mentransformasikannya kembali dari struktur-struktur dunia objektif ke dalam struktur-struktur kesadaran subjektif.

Dalam perspektif pemikiran Berger, internalisasi bukan proses mekanis melainkan konstruktif. Hal ini berdasarkan pandangan antropologi filosofis yang membedakan manusia dengan makhluk hidup lainnya. Riyanto (2009 : 57) mengemukakan.

Manusia adalah makhluk yang memiliki kehendak bebas. Manusia berbeda dengan binatang maupun tumbuhan. Manusia memiliki kapabilitas untuk berpikir, ;mengartikulasikan makna secara sosial dan memiliki kebebasan untuk memilih. Manusia bukanlah makhluk yang pasif, oleh karena itu internalisasi bukan 
sebagai proses belajar yang mekanis tetapi dinamis dan konstruktif.

Internalisasi realitas objektif dan eksternal untuk menjadi objektif ke dalam kesadaran manusia bukan sesuatu yang taken for granted. Manusia memiliki kesadaran yang telah aktif sebelum realitas tersebut terbentuk. Manusia adalah makhluk rasional dan subjektif. Manusia bukanlah aktor yang melayani kepentingan keteraturan struktur melainkan makhluk yang juga berupaya memenuhi kepentingan yang subjektif. Manusia memiliki kemampuan mengkonsepsikan diri dan lingkungannya menurut pretensinya sendiri.

Mekanisme internalisasi adalah sosialisasi. Sosialisasi adalah proses sosial yang dialami setiap individu anggota masyarakat untuk membangun eksistensi diri atau jatidiri, sebab eksistensi diri ditentukan keberadaan dirinya bersama masyarakat dan kebudayaan. Sosialisasi merupakan upaya individu belajar mencapai pengertian tentang diri, alam lingkungan, dan kehidupan sosial di masyarakatnya. Konsep diri sebagai kesadaran subjektif individu tidak dilahirkan dengan suatu konsep diri, melainkan secara bertahap individu memperoleh suatu konsep diri dalam interaksinya dengan orang lain sebagai bagian dari proses yang sama di mana pikiran itu sendiri muncul. Konsep diri terdiri dari kesadaran individu mengenai keterlibatannya yang khusus dalam seperangkat hubungan sosial yang sedang berlangsung dalam suatu komunitas yang terorganisasi. Heidegger (1996 : 51-52) mengemukakan "Being in is thus the formal existential expression of being of Da-sein which has the essential constitution of being in the world. Being together with the world... Being which are objectively present within the world ...can be together with the other". Being adalah "ada-dalam-dunia". "Adadalam-dunia" bukan berarti berada dalam dunia privat melainkan selalu dalam dunia yang dialami bersama.
Kehidupan sosial membawa individuindividu anggota masyarakat mengalami faktisitas yaitu menyingkap suatu "keterlemparan" dalam dunia sosio-kultural secara terus menerus. Individu-individu mendapati diri (self) terlempar ke suatu dunia yang menentukan kebermaknaan “objek-objek" bagi dirinya. Objek-objek itu berupa keseluruhan tatanan sosial dan budaya. Karakteristik faktisitas menampilkan struktur yang dikatakan Heidegger sebagai being-already-in the world (berada-dalamdunia). Individu adalah Dasein yang menemukan dirinya telah berada di dunia yang bukan dunianya sendiri melainkan dunia bersama, bermakna yang terwariskan secara historis. Individu dalam faktistias budaya masyarakatnya merupakan Dasein yang dalam kesehariannya merupakan manusia massa. Dalam kesibukan sehariharinya individu-individu bergaul, berinteraksi dengan anggota masyarakat kehilangan pengertian tentang siapa dirinya sesungguhnya karena tenggelam dalam suatu ke-massa-an. Di sinilah Heidegger menurut Adian (2003 : 35) membedakan antara dua modus eksistensi yaitu "otentik dan inotentik. Otentik adalah kesadaran bahwa akulah yang harus menentukan pilihanku sendiri, sementara modus eksistensi inotentik adalah hilangnya kesadaran akan aku yang otentik".

Sartre (1948) membedakan antara dua jenis cara berada dalam dunia. Yang pertama adalah etre-pour-soi dan kedua etre-ensoi. Etre-pour-soi (being-for-itself, atau adabagi-dirinya) menunjuk pada kesadaran atau manusia, sedangkan etre-ensoi (beingin-itself, ada-dalam-dirinya) menunjuk pada benda. Eksistensi individu sehari-hari adalah hidup dan eksistensi melalui kesadaran pra-reflektif. Dalam kesadaran pra-reflektif, subjek bukanlah subjek yang mengarahkan kesadarannya pada perbuatan-perbuatannya sendiri, melainkan pada sesuatu (objek) yang sedang diperbuatnya. Di samping itu, kesadaran pra-reflektif pun menopang 
kesadaran reflektif. Kesadaran reflektif tercapai berkat keterarahan kesadaran subjek pada perbuatan-perbuatannya sendiri, dalam hubungannya dengan objek. Kesadaran reflektif adalah kesadaran yang membuat kesadaran pra-reflektif menjadi tematik, atau, dengan perkataan lain kesadaran yang membuat kesadaran yang tidak-disadari menjadi "kesadaran yang disadari".

\section{METODE PENELITIAN}

Lokasi penelitian di Desa Kemiren Kecamatan Glagah. Subjek penelitian adalah remaja Osing Desa Kemiren. Remaja tersebut adalah siswa Sekolah Menengah Atas (SMA) atau sederajat. Ada beberapa pertimbangan memilih remaja Osing sebagai subjek penelitian yaitu (1) remaja memiliki kesadaran tentang keberadaan dirinya dan mempunyai kemampuan melakukan transaksional pemikiran dengan orang lain; (2) remaja memiliki kemampuan merasionalkan terhadap sesuatu yang diberikan kepadanya. Penelusuran subjek dilakukan secara snowball.

Konstruksi sosial adalah pengalaman subjektif penuh makna yang terbentuk dari dialektika antara diri dan dunia sosio-kultural melalui eksternalisasi, objektivasi, dan internalisasi. Penelitian beraksentuasi pada pengalaman bermakna individu-individu, sehingga penelitian ini merupakan penelitian kualitatif dengan metode fenomenologi. Teknik pengumpulan data adalah wawancara, observasi, dan dokumentasi. Uji kredibilitas data melalui upaya memperpanjang pelaksanaan penelitian hingga 1 tahun lebih, traingulasi sumber data maupun teknik pengumpulan data, analis kasus negatif, member check, serta pengembangan sensivitas peneliti terhadap penelitian melalui diskusi dengan pakar dan membaca berbagai referensi yang relevan.

Teknik analisis data menggunakan analisis data model Miles dan Huberman. Teknik analisis data menurut Miles dan Huberman (1994 : 10-11) adalah 'analisis data dilakukan secara kontinyu, berulang, dan terusmenerus dimulai dari reduksi data (data reduction), penyajian data (data display), dan conclusion drawing/verivication'. Analisis data pada studi ini dilakukan selama proses pengumpulan data baik pada tahap studi pendahuluan atau "pra-penelitian" maupun pada tahap penelitian (sesudah proposal disertasi disetujui).

Bagan di bawah ini merupakan deskripsi ringkas keseluruhan proses penelitian di lapangan.

Gambar 1 Proses Penelitian

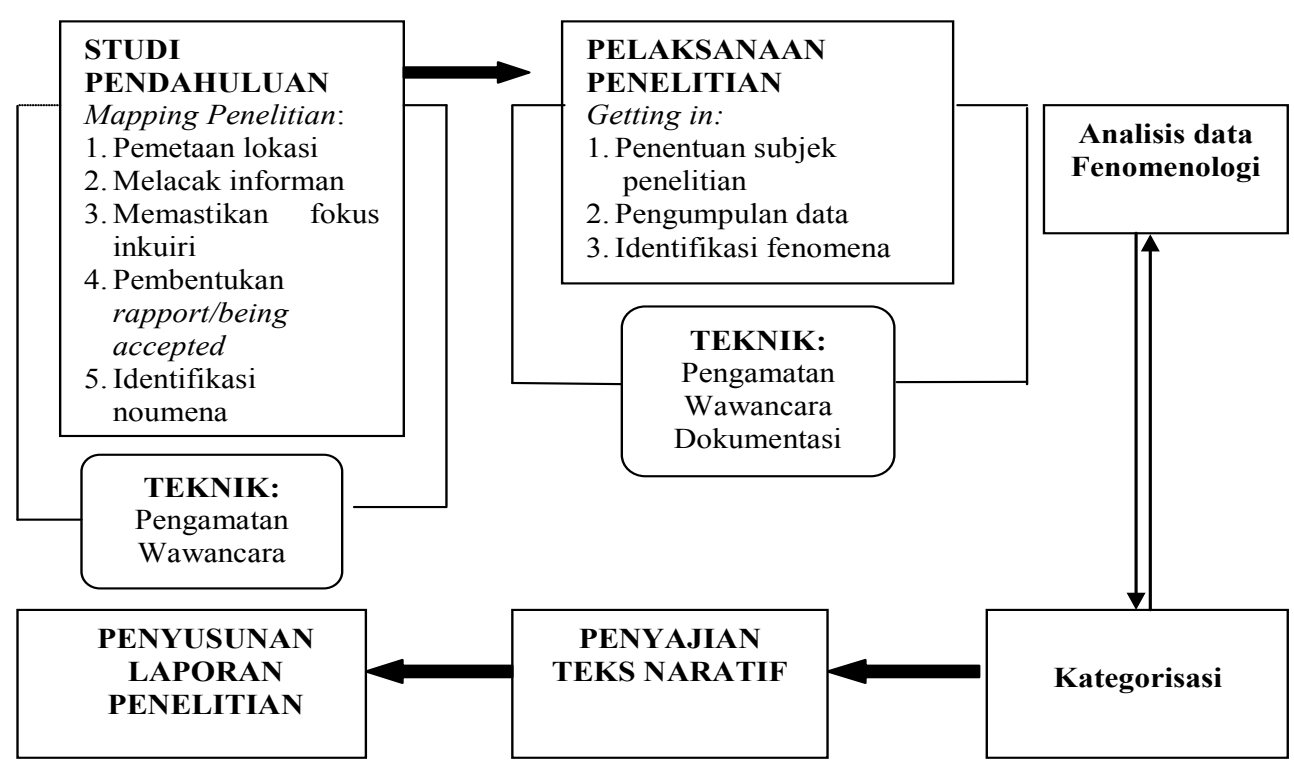




\section{HASIL PENELITIAN DAN PEMBAHASAN}

Ritus Buyut Cili adalah fenomena intensionalitas masyarakat Osing pada dunia esoterisme ketuhanan. Ritus Buyut Cili merupakan refleksi sikap hidup mendasar masyarakat Osing yang mencerminkan pandangan hidup berorientasi pada nilainilai berdimensi transenden. Ritus Buyut Cili sebagai fenomena wujud Tuhan yang dikonstruksi dianggap nyata sebagai Tuhan yang ada, hadir, dan dekat dengan kehidupan masyarakat Osing. Ritus Buyut Cili tidak hanya menjadi bagian dari sistem kepercayaan dan pengetahuan, tetapi ritus itu juga menjadi fakta sosial non material. Ritus Buyut Cili dan dunia esoterisme ketuhanannya menjadi kenyataan hidup sehari-hari masyarakat dan remaja Osing.

Remaja Osing yang lahir, tumbuh, dan berkembang di masyarakat dan kebudayaan Osing tidak dapat dipisahkan dari mozaik kultur ritus Buyut Cili sebagai esoterisme agama budaya Osing. Remaja Osing bersosialisasi dan mempelajari kenyataan sosial sinkretisasi agama dan transformasi nilai-nilai spiritual ketuhanan serta transenden yang bersumber dari kreativitas atau konstruksi subjektif masyarakat maupun ajaran agama-agama besar.

Persepsi masyarakat Osing tentang sifatsifat Buyut Cili yang dihayatinya dari sifatsifat Tuhan dalam kesadaran mereka sebagai umat Islam merupakan proses tipifikasi atau klasifikasi pengalaman dengan melihat keserupaan. Pengalaman ini merupakan pengalaman batin. Rasa aman, makmur, sejahtera, sukses, doa terkabul, lulus ujian, keberhasilan panen, dll yang diperoleh masyarakat Osing dari komunikasi mereka dengan Buyut Cili melalui ritus merupakan pengalaman yang dirasakan sebagai sensasi sifat-sifat Tuhan yang diyakini berdasarkan ajaran Islam. Hubungan antar makna yang diorganisir melalui tipifikasi inilah yang melahirkan konstruksi sosial masyarakat

Tabel 1

Realitas Sosial Esoterisme Agama Budaya Osing dalam Ritus Buyut Cili

\begin{tabular}{|c|c|c|}
\hline FENOMENA & MAKNA SUBJEKTIF & KONSTRUKSI SOSIAL \\
\hline Peristiwa mistis Buyut Cili & $\begin{array}{l}\text { Tuhan mahakuasa dan maha } \\
\text { berkehendak }\end{array}$ & \multirow{8}{*}{$\begin{array}{l}\text { Buyut Cili sebagai } \\
\text { perantara bagi hubungan } \\
\text { antara manusia dan } \\
\text { Tuhan yang noumena }\end{array}$} \\
\hline $\begin{array}{l}\text { Penampakan Buyut Cili dalam wujud } \\
\text { bau, manusia, suara, binatang dan sinar }\end{array}$ & $\begin{array}{l}\text { Tuhan ada dan keberadaannya dekat } \\
\text { dengan kehidupan manusia }\end{array}$ & \\
\hline $\begin{array}{l}\text { Arwah Buyut Cili terus hidup sebagai } \\
\text { penjangkung }\end{array}$ & $\begin{array}{l}\text { Tuhan hidup, kekal, maha pengasih dan } \\
\text { maha penyayang }\end{array}$ & \\
\hline $\begin{array}{l}\text { Keanekaragaman bahan sesaji Buyut } \\
\text { Cili }\end{array}$ & $\begin{array}{l}\text { Tuhan maha pemurah dan pelimpah } \\
\text { rejeki }\end{array}$ & \\
\hline $\begin{array}{l}\text { Sesaji Buyut Cili dilindungi oleh } \\
\text { sejumlah larangan }\end{array}$ & Tuhan maha suci & \\
\hline $\begin{array}{l}\text { Nyekar Buyut Cili dengan semerbak } \\
\text { harumnya kembang kanthil atau pecari, } \\
\text { kembang kenanga atau wangsa, sedap } \\
\text { malam, dan bunga mawar }\end{array}$ & Tuhan yang memberi aman & \\
\hline $\begin{array}{l}\text { Tidak boleh ada dua kesenian sakral } \\
\text { sebagai sarana ritus Buyut Cili. } \\
\text { Kesenian barong saja menjadi sarana } \\
\text { ritual, sementara kesenian Seblang harus } \\
\text { dipindahkan ke Desa Olehsari. }\end{array}$ & Tuhan maha esa & \\
\hline $\begin{array}{l}\text { Arak-arakan barong perwujudan Buyut } \\
\text { Cili mengusir roh jahat }\end{array}$ & $\begin{array}{l}\text { Tuhan pencipta alam semesta dan } \\
\text { isinya serta melindungi seluruh penjuru } \\
\text { alam semesta, Tuhan maha memberi } \\
\text { keamanan, dan Tuhan maha perkasa. }\end{array}$ & \\
\hline
\end{tabular}

Sumber : Hasil Pengolahan SPSS 
Osing bahwa ritus Buyut Cili merupakan fenomena spirit ketuhanan. Tipifikasi merupakan proses pembentukan makna sakral oleh masyarakat Osing terhadap objek Buyut Cili. Sifat-sifat yang dimiliki Buyut Cili dianggap sebagai representasi sifat-sifat Tuhan sehingga Buyut Cili dianggap sosok perantara yang dekat dengan Tuhan dan makamnya dikeramatkan seperti pada tabel 1.

Eksternalisasi, objektivasi, dan internalisasi remaja Osing dengan budaya esoterisme religio-magis masyarakatnya merupakan aktualitas eksistensi diri remaja Osing pada dunia sosialnya. Eksternalisasi, objektivasi, dan internalisasi terus-menerus yang dialaminya merupakan bagian dari pengembangan kepribadian dan perolehan budaya. Eksternalisasi, objektivasi, dan internalisasi yang dilakukan remaja Osing merupakan proses pembentukan konsep diri. "Diri" tidak dilahirkan dengan suatu konsep diri, melainkan secara bertahap individu remaja Osing memperolehnya dengan berinteraksi dengan orang lain.

Eksternalisasi, objektivasi, dan internalisasi terhadap esoterisme religio-magis agama budaya Osing adalah strategi adaptasi budaya yang dilakukan oleh setiap individu remaja Osing sebagai usaha mereka mendapatkan

Tabel 2

Eksternalisasi dan Objektivasi Remaja Osing terhadap Ritus Buyut Cili

\begin{tabular}{|c|c|c|c|}
\hline FENOMENA & PENCURAHAN DIRI & $\begin{array}{c}\text { KONSTRUKSI } \\
\text { SOSIAL }\end{array}$ & $\begin{array}{c}\text { MOTIF } \\
\text { TINDAKAN } \\
\end{array}$ \\
\hline $\begin{array}{l}\text { Penampakan Buyut Cili } \\
\text { sebagai kesadaran Tuhan ada } \\
\text { dan dekat }\end{array}$ & $\begin{array}{l}\text { Kedekatan dengan Tuhan merupakan } \\
\text { sensasi yang muncul dari ibadah yang } \\
\text { dilakukan menurut tuntunan Qur'an } \\
\text { dan sunnah rosul, bukan disebabkan } \\
\text { oleh sensasi penampakan hal gaib } \\
\text { yang merubah wujudnya menjadi } \\
\text { manusia, bau, sinar, dan binatang } \\
\text { maupun kesurupan yang berakibat } \\
\text { manusia ketakutan, kemudian } \\
\text { menghamba kepadanya. }\end{array}$ & $\begin{array}{l}\text { Ritus Buyut Cili } \\
\text { merupakan perilaku } \\
\text { religi yang berada di } \\
\text { luar fondasi ihsan, } \\
\text { iman, dan Islam oleh } \\
\text { sebab itu peribadatan ini } \\
\text { mendekatkan manusia } \\
\text { dengan kemusyrikan. } \\
\text { Pusat pandang } \\
\text { Tuhan adalah rohani } \\
\text { berlandaskan ihsan, iman, } \\
\text { dan Islam. }\end{array}$ & $\begin{array}{l}\text { Desakralisasi } \\
\text { sebagai } \\
\text { pembebasan diri } \\
\text { dan pengisolasian } \\
\text { diri dari keyakinan- } \\
\text { keyakinan kepada } \\
\text { dunia mistis Buyut } \\
\text { Cili }\end{array}$ \\
\hline
\end{tabular}

Pemujaan arwah Buyut Cili Penghambaan kepada Tuhan di makam Buyut Cili sebagai dilakukan secara langsung tidak penghambaan manusia melalui perantara arwah kepada Tuhan

Hal tampak nyata orang Osing memuja arwah Buyut Cili adalah mendoakan Buyut Cili bukan bermunajat kepada Buyut Cili

Bersesaji dan slametan untuk Buyut Cili sebagai pendekatan diri manusia kepada Tuhan

\begin{tabular}{lll}
\hline Arak-arakan barong sebagai & Arak-arakan barong atau Ider Bumi & Barong Osing sebagai \\
kesadaran Tuhan yang & merupakan proses konservatori dan & simbol identitas \\
memberi keamanan di segala & transformasi kesenian barong sebagai & masyarakat Osing. \\
penjuru alam semesta dengan & produk local genius masyarakat & \\
segala isinya & Osing. &
\end{tabular}

pengakuan dan legitimasi dari masyarakatnya bahwa diri mereka adalah orang Osing. Eksternalisasi, objektivasi, dan internalisasi remaja Osing terhadap esoterisme religiomagis agama budaya Osing merupakan usaha remaja Osing "mengada" (being) dalam kehidupan masyarakat Osing. Eksternalisasi, objektivasi, dan internalisasi remaja Osing terhadap esoterisme religio-magis agama budaya Osing merupakan tindak mereka 
menguatkan identitas etnik. Identitas ini pada dasarnya bukan sekadar instrumen untuk membedakan diri mereka dengan etnik lainnya, melainkan gambaran perilaku, nilainilai, dan simbol-simbol budaya Osing yang bermakna bagi kehidupannya seperti pada tabel 2 .

Dua konsep penting konstruksi sosial Berger adalah realitas dan pengetahuan. Ritus Buyut Cili merupakan fakta sosial non-material bersifat eksternal, umum, dan memiliki kekuatan memaksa kesadaran masing-masing individu remaja Osing. Terlepas individuindividu ini suka atau tidak, mau atau tidak, ritus Buyut Cili dan esoterisme tetap ada.

KebudayaanrohaniOsingmelaluiinternalisasi menjadi pengetahuan bagi semua remaja Osing. Pengetahuan merupakan keyakinan bahwa esoterisme adalah fenomena dan memiliki karakteristik tertentu. Pengetahuan esoterisme agama budaya Osing adalah realitas di dalam kesadaran individu-individu remaja Osing dan menjadi fakta psikis atau realitas subjektif pada tabel 3 .

Tabel 3

Internalisasi Remaja Osing terhadap Ritus Buyut Cili



Konstruksi sosial remaja Osing terhadap budaya esoterisme religio-magis merupakan proses kognitif pembentukan dan pemaknaan pengetahuan. Konstruksi sosial remaja Osing terhadap budaya esoterisme religio-magis merupakan proses kognitif remaja Osing memaknai realitas sosial yang dijembatani oleh bahasa dan pikiran. Makna-makna yang terbentuk adalah hal penting bag dunia

\section{kesadaran remaja Osing.}

Rasionalitas yang berkembang di kalangan remaja Osing mencakup sikap kognitif yang relatif bebas dari emosi dan lebih menggunakan rasio daripada emosi dalam mengorganisasi buah pikiran tentang persepsi subjektif masyarakat Osing terhadap ritus Buyut Cili dan esoterismenya. Remaja Osing tidak segan mempertanyakan kebenaran 
realitas Tuhan sebagaimana dihayati masyarakat Osing dan menggejala sebagai fenomena ritus Buyut Cili secara rasional. Hal ini bukanlah tindakan sewenang-wenang tetapi merupakan jawaban dan tanggapan tehadap modal rasional yang sudah dimiliki remaja Osing. Ketidakseganan merupakan usaha remaja Osing melindungi keberhasilan

Tabel 4

Kesadaran Reflektif Remaja Osing dan keampuhan strateginya sebagai jalan keluar dari pengaruh berpikir magis dan mistis masyarakatnya. Sebagai akibat dari strategi khususnya itu, remaja Osing mempunyai watak terbuka atau tertutup dalam berpikir dan berpandangan tentang hal-hal yang diyakininya seperti pada tabel 4 .
REALITAS SOSIAL

\begin{tabular}{cl}
\hline & Realitas sosial problematis tidak sesuai dengan ajaran Islam \\
\cline { 2 - 2 } Bealitas sosial sebagai faktisitas yang tidak statis yang bisa didefinisikan \\
RELIGIO-MAGIS OSING & $\begin{array}{l}\text { Kerbeda atau tidak menurut konstruksti subjektif masyarakat Osing } \\
\text { Kebudayaan rohani yang mengandung nilai sosial- kemasyarakatan }\end{array}$ \\
\cline { 2 - 2 } & $\begin{array}{l}\text { Tindakan rasional berorentasi pada nilai sosial- kemasyarakatan } \\
\text { Dramaturgi sosial sebagai pilihan rasional untuk memenuhi dunia } \\
\text { eksistensi sebagai makhluk individu, makhluk sosial, dan makhluk Tuhan } \\
\text { Yang Mahaesa }\end{array}$ \\
\hline
\end{tabular}

Realitas sosial problematis tidak sesuai dengan ajaran Islam

Realitas sosial sebagai faktisitas yang tidak statis yang bisa didefinisikan berbeda atau tidak menurut konstruksti subjektif masyarakat Osing

Kebudayaan rohani yang mengandung nilai sosial- kemasyarakatan

Tindakan rasional berorentasi pada nilai sosial- kemasyarakatan Dramaturgi sosial sebagai pilihan rasional untuk memenuhi dunia eksistensi sebagai makhluk individu, makhluk sosial, dan makhluk Tuhan Yang Mahaesa

\section{KESIMPULAN}

Eksternalisasi, internalisasi, dan objektivasi remaja Osing terhadap ritus Buyut Cili menghasilkan pengetahuan, nilai, dan motif tindakan yang dipahami remaja Osing secara etik maupun emik. Konstruksi sosial remaja Osing terhadap ritus Buyut Cili berdasarkan perspektif etik menghasilkan kemampuan remaja Osing memahami dunia anggapan dan penilaian orang lain bahwa agama budaya Osing dekat dengan kemusyrikan. Konstruksi sosial remaja Osing terhadap ritus Buyut Cili berdasarkan perspektif emik menghasilkan kemampuan remaja Osing memahami dunia pandang (world view) masyarakat Osing tentang Tuhan dan menemukan persamaan antara agama wahyu dan agama bumi/ alam/budaya. Persamaan yang ditemukan merupakan equilibirasi pengetahuan yang menjembatani sudut pandang etik dan emik memahami realitas sosial ritus Buyut Cili. Remaja Osing mengembangkan keterampilan sosial berdasarkan equilibirasi pengetahuan nilai-nilai dunia transenden agama budaya Osing. Remaja Osing bersikap toleransi, empati, kooperatif, dan peduli menyikapi perbedaan penghayatan dunia esoterisme dalam kehidupan masyarakat. Keterampilan sosial ini merupakan motif tindakan yang tidak hanya sebagai wujud komitmen sosial remaja Osing, tetapi motif itu juga sebagai manifestasi kesadaran situasionalnya.

Konstruksi remaja Osing tehadap esoterisme ritus Buyut Cili menunjukkan adanya kesadaran reflektif. Kesadaran ini berhubngan dengan keadaran pra-reflektif. Hubungan kesadaran di antara keduanya menunjukkan kesadaran reflektif merupakan 
kesadaran yang membuat kesadaran prareflektif menjadi tematik yakni kesadaran yang membuat kesadaran yang tidak disadari menjadi kesadaran yang disadari.
Berdasarkan kesadaran reflektif remaja Osing menghadirkan diri dan dunia sosialnya secara rasional.

\section{DAFTAR PUSTAKA}

Adian, D. G. (2003), Martin Heidegger, Jakarta: Teraju.

Berger, P, (1994), Langit Suci: Agama Sebagai Realitas Sosial, Jakarta: LP3ES.

Berger, P. L. \& Thomas Luckmann, (1990), Tafsir Sosial atas Kenyataan: Risalah tentang Sosiologi Pengetahuan (diterjemahkan dari buku asli The Social Construction of Reality oleh Hasan Basari). Jakarta: LP3ES.

Danandjaja, J. (1994), Folklor Indonesia Ilmu Gosip, Dongeng, dan lain-lain, Jakarta: Grafiti Press

Dhavamony, M. (1995), Fenomenologi Agama (judul asli: Phenomenology of Religion), terj. A. Sudiarja, dkk, Yogyakarta: Kanisius.

Eliade, M. (2002), The Sacred and The Profane, terj. Nuwanto, Yogyakarta: Fajar Pustaka Baru.

Endraswara, S. (2003), Falsafah Hidup Jawa. Tangerang: Cakrawala.

Heidegger, M. (1996), Being and Time, terj. Joan Stambaugh, State University of New York Press

Lukes, S. (1972), Emile Durkheim: His Life and Work, New York: Harper \& Row.

O’dea, T. (1996), Sosiologi Agama Suatu Pengenalan Awal, Jakarta: Raja Grafindo Persada.

Ritzer, G.(1980), A Multiple Paradigm Science, Boston: Allyn and Bacon

Riyanto, G.(2009), Peter L. Berger Perspektif Metateori Pemikiran, Jakarta: LP3ES

Saputra, H.SP, (2008), "Dimensi Religiositas Dan Mekanisme Mistis: Refleksi Budaya Lokal Orang Using Banyuwangi”, Jurnal Ilmu Pengetahuan Sosial, IX (2). 70-74.

Satre, J. P. (1948), Being and Nothingness, tr. Hazel E. Barnes, New York: Philosophical Library

Subaharianto, A. (1996), "Mitologi Buyut Cili Dalam Pandangan Orang Using di Desa Kemiren Kabupaten Banyuwangi”. Laporan Penelitian. Jember: Lembaga Penelitian Universitas Jember.

Sunarlan, (2008), "Using: Masyarakat yang Kaya Kesenian, tetapi sering terbelit maslah politik", dalam Pemetaan Kebudayaan Di Propinsi Jawab Timur: Sebuah Upaya pencarian Nilai-Nilai Positif, Pemerintah Propinsi Jawa Timur: Biro Mental Spiritual.

Suparno, P. (1997), Filsafat Konstruktivisme dalam Pendidikan, Yogjakarta: Kanisius

Thompson, M. (1990), Cultural Theory, San Fransisco: Westview Press.

Vera-Godoy, H. (1971), "Marcell Mauss Sociological System : An Essay in Method Interpretation”, Thesis, Notre Dame, Indiana: University Dame

Waters, M. (1994), Modern Sociological Theory, London: SAGE Publication. 